
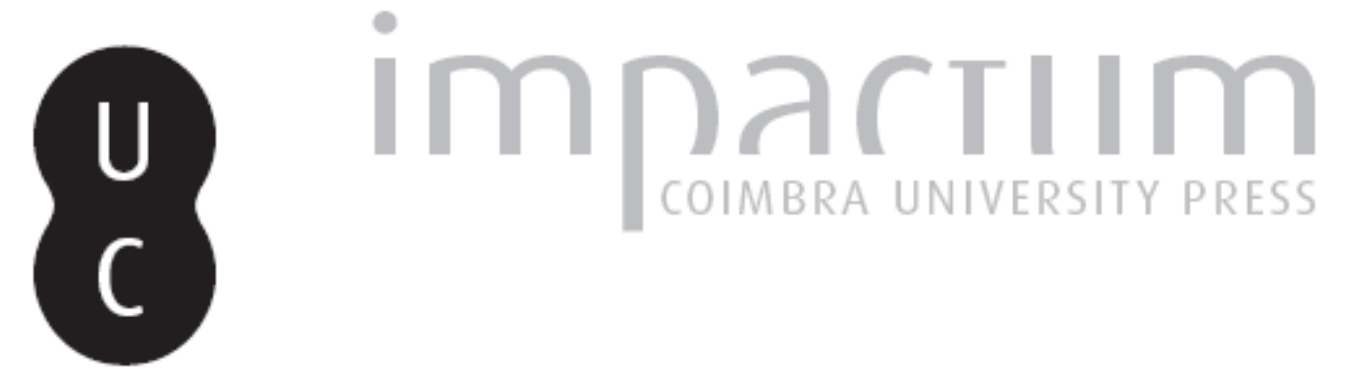

The desacralization of the world in the poetry of Fernando Pessoa

Autor(es): Courteau, Joanna

Publicado por: Imprensa da Universidade de Coimbra

URL persistente:

URI:http://hdl.handle.net/10316.2/45282

DOI:

DOI:https://doi.org/10.14195/2183-8925_8-1_22

Accessed : $\quad$ 26-Apr-2023 10:38:43

A navegação consulta e descarregamento dos títulos inseridos nas Bibliotecas Digitais UC Digitalis, UC Pombalina e UC Impactum, pressupõem a aceitação plena e sem reservas dos Termos e Condições de Uso destas Bibliotecas Digitais, disponíveis em https://digitalis.uc.pt/pt-pt/termos.

Conforme exposto nos referidos Termos e Condições de Uso, o descarregamento de títulos de acesso restrito requer uma licença válida de autorização devendo o utilizador aceder ao(s) documento(s) a partir de um endereço de IP da instituição detentora da supramencionada licença.

Ao utilizador é apenas permitido o descarregamento para uso pessoal, pelo que o emprego do(s) título(s) descarregado(s) para outro fim, designadamente comercial, carece de autorização do respetivo autor ou editor da obra.

Na medida em que todas as obras da UC Digitalis se encontram protegidas pelo Código do Direito de Autor e Direitos Conexos e demais legislação aplicável, toda a cópia, parcial ou total, deste documento, nos casos em que é legalmente admitida, deverá conter ou fazer-se acompanhar por este aviso. 
REVISTA DE HISTÓRIA DAS IDEIAS $\mathbf{8}$

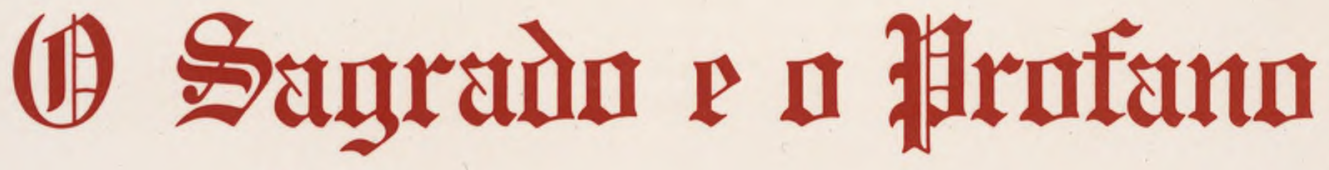 s.1. \\ HOMENAGEM A J. S. DA SILVA DIAS}

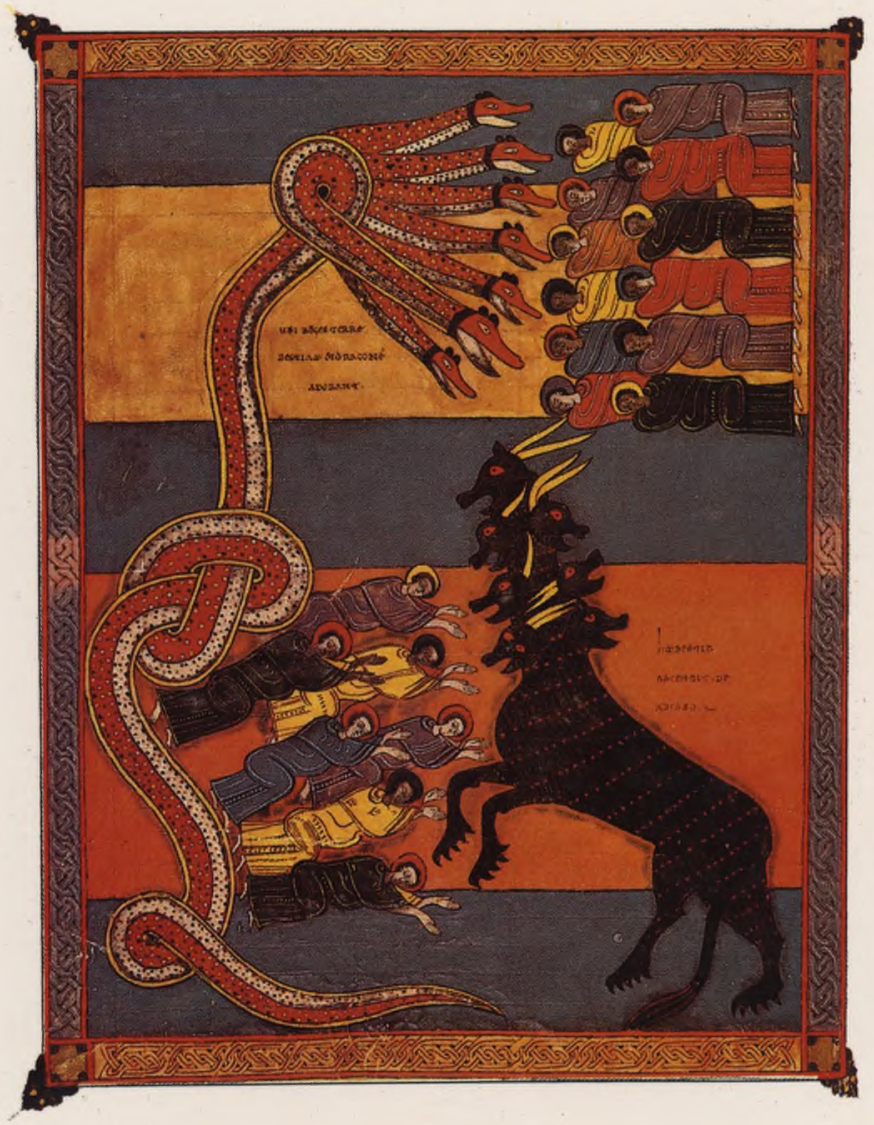

INSTITUTO DE HISTORIA E TEORIA DAS IDEIAS FACULDADE DE LETRAS 


\section{THE DESACRALIZATION OF THE WORLD IN THE POETRY OF FERNANDO PESSOA}

In his 1982 version of Fernando Pessoa: a Obra e o Homem, António Quadros brings together, through a skillful use of the anthologizing technique, Pessoa's diverse ideas regarding religion from Paganism to Occultism 0). Quadros' anthologizing principle allows to place in a total religious perspective the points brought out by Dalila L. Pereira da Costa in O Esoterismo de Fernando Pessoa (2) and Leila Perrone Moisés' in Fernando Pessoa. Aquém do Eu e Além do Outro (3). Viewed from the perspective of António Quadros' anthology, it is possible to see that Fernando Pessoa established a basic outline for the study of history of religion, anticipating in very broad terms the work done by Mircea Eliade, originally published in French in $1976\left({ }^{4}\right)$.

What is particularly striking about the parallel with Eliade is Pessoa's awareness of three of Eliade's basic premises, which are "consciousness of» the «unity of the spiritual history of humanity^ $(5)$, the inherent presence of the sacred in the «structure of consciousness» $\left.{ }^{6}\right)$, and «the ultimate stage of the desacralization», which Eliade considers «the sole, but important religious creation of the modern Western world» $\left({ }^{7}\right)$.

* Iowa State University, U.S.A.

O) Vol. II, Lisboa, Editora Arcádia, 1982, pp. 169-193.

(2) Porto, Lello e Irmão, 1971.

(4) A History of Religious Ideas, vols. I-III. Chicago, The

(3) São Paulo. Martins Fontes Editora, 1982.

University of Chicago Press, 1978.

(5) Vol. I, p. XVI.

(8) Ibidem, p. 5.

(7) Ibidem, p. XVI. 
It is this last parallel that is the object of this study. I would like to show that Pessoa examines closely the desacralization of the modern Western world and establishes a relationship between this occurrence and the existential anguish. Furthermore, the only possible cure to the existential anguish is suggested in a return of the sacred element to the Universe, especially the sacred element of Paganism ( $\left.{ }^{8}\right)$. In this choice of Paganism, I see not so much the fundamental rejection of Christianity per se, as theorized by Leila Perrone Moisés $\left({ }^{9}\right)$, but a turning away from the rational Tomistic scrutiny, which inevitably leads to the existential angst.

Pessoa's awareness of the desacralization of the modern Western world is shown, with great effectiveness in three poems in pasticular: «O Último Sortilégio», «Símbolos» and "As Musas». It is consistent with Pessoa's heteronymic scheme that these poems should be part of the opus authored by Ele-mesmo and by Álvaro de Campos, since the other two main heteronyms, Mestre Caeiro and his closest disciple, Ricardo Réis, devote their writings to the expression and predication of the tenets of Paganism.

«O Último Sortilégio», a poem whose persona is the mother-earth, examines the extent of loss of sacred elements embodied in the planet Earth itself, and emphasizes the profanization of all those elements that once were sacred. The oldest deity in Greek Cosmology, the Ghea, has stopped being God,

Já meu furor astral não é divino

Nem meu corpo pensado é já um Deus.

to become simply the road under our feet,

E ao luar que sobe além dos matagais

Não sou mais do que os bosques ou a estrada $\left({ }^{10}\right)$.

The poem «Símbolos» shows the presence of sacred symbology in the entire world around us in contrast with a total absence of awareness of this symbology on the part of the modern man, who interprets all phenomena around him as simple manifestations of material reality,

(8) Perrone Moisés, p. 115.

(9) Ibidem, p. 116.

(10) Fernando Pessoa, Poesias, vol. I, Lisboa, Edições Ática, 1958, p. 230. 
Que o sol seja um símbolo, está bem...

Que a lua seja um símbolo, está bem...

Que a terra seja um símbolo, está bem...

Mas quem repara no sol senão quando a chuva cessa

Mas quem repara na lua senão para achar

Bela a luz que ela espalha, e não bem ela?

Mas quem repara na terra, que é o que pisa?

Chama terra aos campos, às árvores, aos montes $\mathrm{O}^{1}$ ).

This poem expresses precisely what Eliade calls «the scientific desacralization of nature» $\left({ }^{12}\right)$.

The poem «As Musas» shows that not only the physical elements all around us have been deprived of their sacred status, human mind itself and the creative process that it embodies has been separated from the sacred source of artistic inspiration,

Os antigos invocavam as Musas

Nós invócame-nos a nós mesmos.

in order to give a solipsistic, narcissistic and hollow home to the essential profanization of the modern creative act.

Quantas vezes me tenho debruçado

Sobre o poço que me suponho

E balido «Áh!» para ouvir um eco

E não tenho ouvido mais que o visto

$\mathrm{O}$ vago alvor escuro com que a água resplandece

Lá na inutilidade do fundo...

Nenhum eco para mim...

Só vagamente uma cara,

Que deve ser a minha, por não poder ser de outro.

E uma coisa quase invisível $\left({ }^{13}\right)$.

The poem «Esta velha angústia» of Álvaro de Campos expresses particularly well the link between existential anguish and desacralization of the universe, and the desire to cure the anguish by a return to a sacred reality, no matter how grotesque.

(1:L) Fernando Pessoa, Ficções do Interlúdio, vol. IV, Poesias de Álvaro de Campos, Rio de Janeiro, Biblioteca Manancial, 1976, p. 166.

(12) Mircea Eliade, The Sacred and the Profane: The Nature of Religion, New York, Harper and Row, 1961, p. 151.

(13) Álvaro de Campos, p. 169. 


\section{O Sagrado e o Profano}

Esta velha angústia,

Esta angústia que trago há séculos em mim,

Transbordou da vasilha,

Em lágrimas, em grandes imaginações,

Em sonhos em estilo de pesadelo sem terror,

Em grandes emoções súbitas sem sentido nenhum.

Transbordou.

Mal sei como conduzir-me na vida

Com este mal-estar a fazer-me pregas na alma!

Se ao menos endoidecesse deveras?

Mas não: é este estar entre,

Este quase,

Este poder ser que...,

Isto.

Se ao menos eu tivesse uma religião qualquer!

Por exemplo, por aquele manipanso

Que havia em casa, lá nessa, trazido de África.

Era feissimo, era grotesco,

Mas havia nele a divindade de tudo em que se crê.

Se eu pudesse crer num manipanso qualquer...

Júpiter, Jeová, a Humanidade...

Qualquer serviria,

Pois o que é tudo senão o que pensamos de tudo? $\left({ }^{14}\right)$

The poem about the death of o dono da Tabacaria shows that in the absence of the sacred, a physical place, because of its absolute fixedness, may assume a sacred dimension, a dimension which, although not rooted in the cosmological sacred, is a useful substitute because it provides a focal centralized point in the chaos of ordinary existence.

Cruz na porta da tabacaria!

Quem morreu? O próprio Alves? Dou

Ao diabo o bem-'star que trazia.

Desde ontem a cidade mudou.

Quem era? Ora, era quem eu via.

Todos ofc dias o via. Estou

Agora sem essa monotonia.

Desde ontem a cidade mudou.

Ele era o dono da tabacaria.

Um ponto de referência de quem sou.

Eu passava ali de noite e de dia.

Desde ontem a cidade mudou.

(14) Ibidem, pp. 157-158. 
Meu coração tem pouca alegria,

E isto diz que é morte aquilo onde estou.

Horror fechado da tabacaria!

Desde ontem a cidade mudou.

Mas ao menos a ele alguém o via,

Ele era fixo, eu, o que vou,

Se morrer, não falto, e ninguém diria:

Desde ontem a cidade mudou (15).

In the two poems viewed together, one can see the desire for a reality that is organized along vectors that are fixed and absolute. The desire to return to the sacred time and to sacred space permits an escape from the indistinguished and undifferentiated time and space of desacralized reality. This is particularly evident in the last stanza of the second poem, in which the space occupied by the poetic persona is totally undifferentiated from any other space, which lack of differentiation will lead to the persona's purely organic, scientifically desacralized, death, unnoticed by those around. Ultimately, then, in this yearning for a fixed absolute center, we can see expressed a desire for some form of immortality, a desire which, when denied by reason, results in existential anguish.

The last poem to be examined in the discussion of the cycle of a desacralized world which leads to existential anguish which leads to a desire for a return to the sacred is the poem «Apontamento». This poem is all the more interesting because it suggets the only solution available to the modern man, within the context of the Western world.

A minha alma partiu-se como um vaso vazio.

Caiu pela escada excessivamente abaixo.

Caiu das mãos da criada descuidada.

Caiu, fez-se'em mais pedaços do que havia loiça no vaso.

Asneira? Impossivel? Sei lá!

Tenho mais sensações do que tinha quando me sentia eu.

Sou em espalhamento de cacos sobre um capacho por

[sacudir.

Fiz barulho na queda como um vaso que se partia.

Os deuses que há debruçam-se do parapeito da escada.

E fitam os cacos que a criada deles fez de mim.

Não se zanguem com ela.

São tolerantes com ela.

O que era eu um vaso vazio?

(15) Ibidem, p. 143. 
Olham os cacos absurdamente conscientes,

Mas conscientes de si mesmos, não conscientes deles.

Olham e sorriem.

Sorriem tolerantes à criada involuntária.

Alastra a grande escadaria atapetada de estrelas.

Um caco brilha, virado do exterior lustroso, entre os astros.

A minha obra? A minha alma principal? A minha vida?

Um caco.

E os deuses olham-o especialmente, pois não sabem por [que ficou ali $\left({ }^{16}\right)$.

The one common view of religion that emerges from the study of several modern religious theorists $\left({ }^{17}\right)$ is a view of religion as an organizing principle, a principle that imposes order upon the pre-sacred chaos. The neo-pagan solution proposed by Ricardo Réis, based on the teaching of Mestre Caeiro, would indeed restore order to the chaotic universe in which modern man finds himself. The modern occidental mind might be able to assimilate Paganism under the guise of Zen. Leila Perrone Moisés shows quite skillfully the affinity between Mestre Caeiro's Paganism and the Doctrine of Zen $\left({ }^{18}\right)$. Yet because Zen requires the suspension of thinking processes, its assimilation becomes a virtual impossibility for the Western man. That the acceptance of Zen would require a radical alteration of the Western man's way of being is amply substantiated in the controversial contemporary work of Robert Pirsig, Zen and the Art of Motorcycle Maintenance: an Inquiry into Values $\left({ }^{19}\right)$.

It is precisely at the moment of realization of the virtual impossibility of Mestre Caeiro's posture for the modern Western man that the poem «Apontamento» becomes immensely significant.

At first the poem seems to express precisely the opposite of the organizing effect of the sacred. The persona's soul, which

(16) Ibidem, p. 133.

(17) Cf. Emile Durkheim, The Elementary Forms of the Religious Life, New York, MacMillan Publishing Co., 1968; Andrew R. Greeley, Religion: A Secular Theory, New York, MacMillan Publishing Company, 1982; Leszek Kolakowski, Religion, New York, Oxford University Press, 1982; W. Brede Kristensen, The Meaning of Religion, The Hague, Martinus Nijhoff, 1960; Max Scheler, On the Eternal in Man, London, Camelot Press, 1960.

(18) Pp. 118-159.

(19) New York, Morrow Books, 1974. 
consists of a form ordered and organized along the lines of a vase, is dropped by a maid, becoming shattered into a chaotic presence of a thousand indistinct and undifferentiated pieces. The maid's careless act brings about fragmentation and chaos to the jar's original form. Yet the gods, from whom all order is derived, are not angry at her. The poetic persona questions the gods' tolerance. There may be two reasons for the gods' forgiveness; one is that the jar may have been totally empty, deprived of content and meaning; the other, that the fragmented pieces have neither lost their essential nature, nor their awareness of their essential nature. The jar's original form could signify the emptiness of the old set of fossilized religion in which the jar would represent an archeological find, a merely formal vestige of an old belief. Its shattering returns it to a pre-sacred primordial chaos, but not truly primordial because it has not been turned to dust. Hence in the annihilation of its form lies the possibility of a new beginning, the eternal return. But once again, the possibility of the cyclical return to the origins is denied; shattered into a thousand pieces, the jar can never be reformed or remolded completely. The jar, therefore, could be a metonymy for the sacred element in the modern world, the sacred element which can never be recaptured completely and be the same as it was when it was nurtured by the loving gaze of the gods. But among all the shattered pieces, one piece can absorb and reflect the sacred brilliance of the stars. This piece, representing the modern man's retention of the sacred element within his essential soul, the creative part of his life, presents a mystery to itself and to the gods. Without willing or adopting a religious posture, the modern man has managed to retain a sacred element in his creativity, an element, which like all religious elements is totally irrational, and, because of this irrationality, a total mystery to gods and to itself. This irrational, mysterious, creative sacred glimmer, while indicative of man's inherent inability to return to the sacred origins, has the power of saving man from the existential angst by eternalizing the sacred element in his creative work. Thus, in effect, this poem offers the antidote to the hollow solipsistic profanization of the creative act lamented in the earlier quoted poem, «As Musas».

It is significant to note, therefore, that it is not in the eternal teaching of Mestre but in the fugitive and fragmented glimmer of hope of Alvaro de Campos that we can find the solution to modern Western man's existential predicament in the desacralized world. The existential «saudade» brought 


\section{O Sagrado e o Profano}

on by the «profound disappointment (italics mine) with the present» $\left({ }^{20}\right)$ can at least in part be resolved with the creative act of «Apontamento».

(20) Alfredo Antunes, Saudade e Profetismo em Fernando Pessoa, Braga, Faculdade de Filosofia, 1983, p. 215. 